\title{
Administrative Action and the Doctrine of Proportionality in India
}

\author{
Ajoy P.B. \\ (Advocate, High Court of Kerala, Cochin, India)
}

\begin{abstract}
The scope of judicial review of administrative action has been the central theme of discussion in administrative law. Initially common law countries including India adopted the doctrine of wednesbury reasonableness to review administrative action. But subsequently under influence of civil law systems and Strasburg jurisprudence the doctrine of proportionality is being gradually accepted as the standard of judicial review by the common law countries. There are two models of proportionality namely the British Model or the state limiting conception of proportionality and the European model or the optimizing concept of proportionality. Of the two the European model is more objective and hence preferred. The Indian Supreme Court accepted the doctrine of proportionality in the year 2000. Yet even today the Indian legal system has not come to terms with the doctrine. There is hardly any case where the doctrine has been practically applied. The need of the hour is to increasingly apply the doctrine of proportionality to review administrative action in India.

Key words: Discretionary area of judgment, Doctrine of proportionality, Judicial deference, Judicial restraint. Margin of appreciation, Margin of discretion, Wednesbury reasonableness,
\end{abstract}

\section{Introduction}

Judicial review of legislative and executive action has been one of the most important developments in the field of public law in the last century. Though the concept of judicial review was developed way back in 1803 in the famous case of Marbury v. Madison ${ }^{1}$, it found wide application only in the later periods of the $20^{\text {th }}$ Century, when in the aftermath of the World War II, democracy came to be the governing political principle in most parts of the world. Since then the scope and ambit of judicial review has been one of the central themes of discussion in the branch of administrative law.

Among the two - executive and legislative actions - it is the judicial review of executive action (administrative action) that has assimilated much content enrichment, particularly in the last two decades. The growth of modern welfare state coupled with the technological advances has resulted in the legislature not only leaving wide areas of discretion to the administrative authority but also even delegating many of its powers and functions. This has resulted in the modern day bureaucrat becoming extremely powerful. This often leads to misuse of discretion vested in him there by requiring frequent judicial intervention. However this intervention should not result in the judiciary encroaching into areas reserved for the executive. Consequently, the scope and ambit of judicial review must be limited to the extent just necessary to prevent the abuse of the discretion conferred on the executive.

To achieve this limiting function of judicial review, common law systems and civil law systems reacted differently and developed different processes. In common law jurisdictions the concept of secondary review was developed to achieve this limiting function of judicial review. Under the concept of secondary review the courts would strike down administrative orders only if it suffers the vice of wednesbury unreasonableness ${ }^{2}$ which means that the order must be so absurd that no sensible person could ever dream that it lay within the powers of the administrative authority. The civil law jurisdictions on the other hand developed the concept of proportionality based review (primary review) which is a much more intensive form of judicial review. The principle of proportionality ordains that the administrative measure must not be more drastic than is necessary for attaining the desired result ${ }^{3}$. Though the common law countries prefer secondary review, it could not ignore proportionality based review for long. This was not only because of the advantages associated with proportionality based review but also because of the establishment of an European court and the consequential growth of a separate pan European jurisprudence primarily based on civil law concepts.

India, a former colonial state of British Empire, inherited from British India, the common law system. After Independence, India chose to retain the common law system without much change. Indian courts have

\footnotetext{
${ }^{1} 5$ US 137 (1803)

${ }^{2}$ See Associated Picture House v. Wednesbury Corporation (1947) 2 All ER 74 (CA).

${ }^{3}$ Justice Anand Byrareddy, Proportionality vis-à-vis irrationality in administrative law (2008) 7 SCC J-29, p.32
} 
always found it desirable to follow English precedents while deciding domestic cases. This has virtually been the case in the development of administrative law in India. Inspite of Article 226/Article 32 read with Article 13 of the Constitution of India giving the constitutional courts much wider scope to interfere with executive orders, the Indian courts have chosen to follow the English concept of wednesbury reasonableness. However, with the doctrine of proportionality fast gaining currency across the world including common law countries, the Indian legal system could not remain closed for long and in the case of Omkumar v Union of India ${ }^{4}$ the Indian Supreme Court accepted the doctrine of proportionality as a part of Indian law.

This article seeks to analyze the theoretical aspects of the doctrine of proportionality and the scope of its applicability to the Indian legal system.

\section{Judicial Review: Wednesbury Unreasonableness Versus Proportionality.}

The broad contours of the external structure of judicial review have been laid down by Lord Diplock in the case of Council of Civil Service Unions. v. Minister for the Civil Services ${ }^{5}$ as: 'illegality', 'irrationality' and 'procedural impropriety' ${ }^{6}$. This tripartite classification demarcates judicial review's external structure. However it is not exhaustive, nor is the grounds it classifies mutually exclusive. ${ }^{7}$ Nevertheless all major authors of books on judicial review use this classification method ${ }^{8}$. Many developments have occurred within the concept of judicial review including the decline of prerogative powers and immunity, rise and fall of the concept of jurisdiction, and the formalization and expansion of legitimate expectation. However all these changes can be accommodated and neatly housed within Lord Diplock's tripartite classification.

Lord Diplock has himself very neatly defined all the three structures within his classification - namely illegality, irrationality and procedural impropriety ${ }^{9}$ but it is the concept of irrationality that is of importance in this work.

\section{Irrationality and Wednesbury Unreasonableness}

While defining irrationality Lord Diplock equated it with 'wednesbury unreasonableness ${ }^{10}$. The concept of' 'wednesbury unreasonableness' was developed in the case of Associated Picture House v. Wednesbury Corporation ${ }^{11}$ and hence the name 'wednesbury unreasonableness'. It simply means that administrative discretion should be exercised reasonably. Accordingly, a person entrusted with discretion must direct himself properly in law. He must call his attention to matters which he is bound to consider. He must exclude from his consideration matters which are irrelevant to the subject he has to consider. If he does not obey those rules he can be said to be acting unreasonably ${ }^{12}$. Lord Diplock beautifully sums up 'wednesbury unreasonableness' as a principle that applies to a decision which is so outrageous in its defiance of logic or of accepted moral standards that no sensible person who applied his mind to the question to be decided could have arrived at $\mathrm{it}^{13}$. Quite obviously the concept of wednesbury unreasonableness is extremely vague and is not capable of objective evaluation. Hence wednesbury unreasonableness cannot be defined in the form of standard tests for universal application.

\section{Proportionality}

The classical definition of proportionality has been given by none other than Lord Diplock when his Lordship rather ponderously stated "you must not use a steam hammer to crack a nut if a nut cracker would do" ${ }^{\prime 14}$ Thus proportionality broadly requires that government action must be no more intrusive than is necessary to meet an important public purpose ${ }^{15}$. However the greatest advantage of proportionality as a tool of judicial review is its ability to provide objective criteria for analysis. It is possible to apply this doctrine to the facts of a case through the use of various tests.

Lord Diplock even while giving the tripartite classification admits that proportionality in the future would be an additional ground of review ${ }^{16}$. However, today most authors accept proportionality as an additional

\footnotetext{
${ }^{4}$ Infra n. 22

${ }^{5}$ Infra n. 9

${ }^{6}$ Id., p. 950

${ }^{7}$ Wheeler v. Leiscester City Council (1985) A.C. 1054, per Lord Roskill, p. 1078

${ }^{8}$ For e.g., See John Adler, General Principles of Constitutional and Administrative law, (4 $4^{\text {th }}$ ed., 2002) p. 368

${ }^{9}$ Council of Civil Service Unions. v. Minister for the Civil Services (1984) 3 All ER 935, pp. 950, 951

${ }^{10}$ Ibid., p. 951

${ }^{11}$ (1947) 2 All ER 680 (CA)

${ }^{12}$ Ibid., pp.682, 683

${ }^{13}$ See Supra n. 9 at p. 951

${ }^{14} R$ v. Goldsmith (1983) 1 WLR 151, p. 155

${ }^{15}$ See Supra n. 8 at p. 385

${ }^{16}$ See Supra n. 9 at p 950
} 
head of judicial review within the concept of irrationality ${ }^{17}$. Thus proportionality and wednesbury unreasonableness is seen as the two aspects of irrationality. Initially proportionality was only a competitor with wednesbury unreasonableness but because of the high degree of objectivity associated with proportionality and the vast improvements that the concept has undergone in the last decade and a half, it is seeking to totally replace Wednesbury unreasonableness as the only sub-head of review under the concept of irrationality.

\section{Margin of Appreciation}

The proponents of the doctrine of proportionality always maintained the view that judicial review using proportionality is different from an appeal. An appeal allows the appellate body to decide the whole matter again $^{18}$. Hence it involves a thorough reconsideration of the whole decision ${ }^{19}$ whereas judicial review is concerned only with ensuring that legal standards are complied with ${ }^{20}$. Proportionality form of judicial review achieves this by ascertaining whether the decision maker has adopted the least restrictive choice of measures and has maintained a proper balance between the possible adverse effects of the decision on the rights, liberties and interests of the persons affected by the decision. This does not involve a full blown merits review. Further the decision maker is given an area of discretion or range of choices. The width of the area of discretion depends upon the subject matter ${ }^{21}$ and type/nature of rights involved. If the decision maker functions within the area of discretion and makes a choice among the various alternatives available, the courts would not normally question the wisdom of the decision maker. However as M. Jaganatha Rao J. rightly points out, the court may still look into whether the choice made, infringes the rights excessively or not ${ }^{22}$.

In the language of Strasburg jurisprudence (European Court) this range of choice allotted to the decision maker is called the Margin of Appreciation. It refers to the power of the contracting states ${ }^{23}$ to enjoy a certain degree of latitude in balancing individual rights and national interests as well as resolving the conflict that emerge as a result of diverse moral convictions.

When the Human Rights Act, 1998 came to be effective in United Kingdom there emerged a consensus that there must be a domestic equivalent of the margin of appreciation. However the domestic 'margin of appreciation' cannot be identical to the European one, primarily because European court is an international tribunal supervising independent legal systems with legislative, executive and judicial branches. By contrast, the domestic equivalent addresses the relationship of the judiciary to other branches of government, requiring regard to be had at some point, to their assessment of proportionality. An International Court on the other hand has to take into account the cultural diversity of human right conceptions among nations in a way inappropriate for the courts of a single political community ${ }^{24}$. Hence the English Judges and academic writers avoid using the term margin of appreciation and instead prefer terms like "margin of discretion' or "discretionary area of judgment".

According to Julian Rivers, this margin of discretion has two aspects ${ }^{25}$ namely 'Judicial Deference' and 'Judicial Restraint' both of which together determine the width of the margin of discretion. The concept of judicial deference is grounded on concept of institutional competence of non judicial bodies to determine the proportionality of the limitation imposed on rights of the citizens. Quite often the courts would not have the expertise to determine whether an act is proportional or not and in such situations the court will accept the discretion of the decision maker. On the other hand judicial restraint relates to the legality aspect of judicial review. Suppose that in a particular case there are two or more proportionate decisions available and the decision maker bona fide make one choice, then in such situation the court will not interfere with the decision not because of deterrence, but because the court exercises restraint. There is no intrinsic reason why a judge could not make a choice as well but such a choice would be illegitimate. Their role is to secure legality not correctness $^{26}$.

\section{TWO MODELS OF PROPORTIONALITY}

Over the last few decades, two prominent conceptions or models of proportionality has emerged. The two models can be tentatively named as

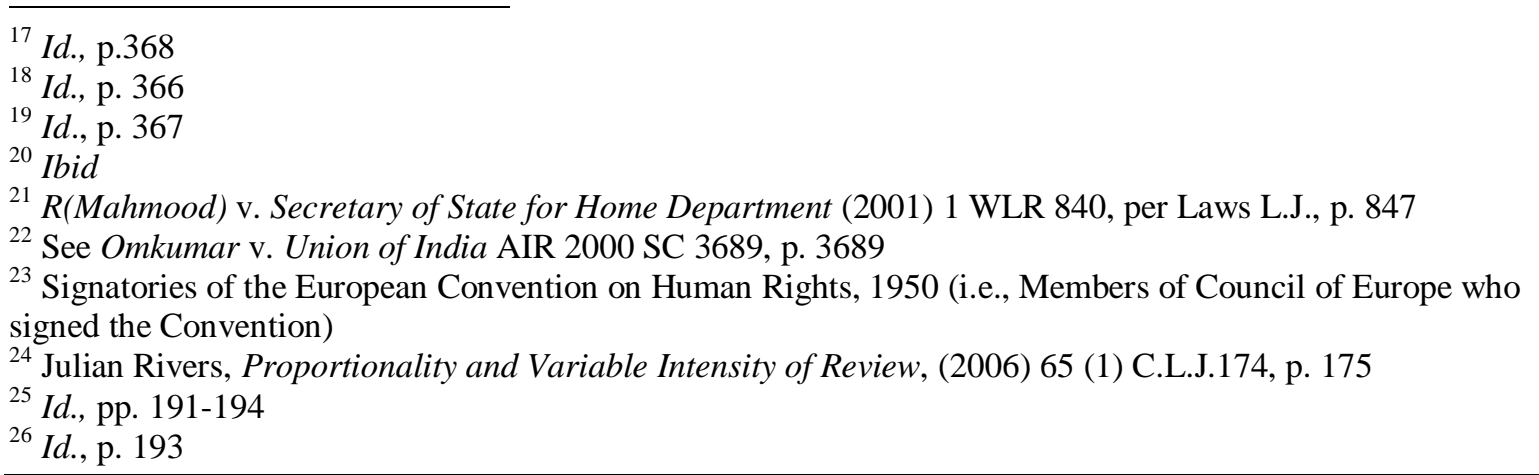


1) The British model or the state-limiting conception of proportionality ${ }^{27}$ and

2) The European model or the optimising conception of proportionality ${ }^{28}$.

Both models suggest different test that the court must undertake to determine whether a decision set is proportionate or not.

\section{British Model}

The British model as expounded by Lord Stynn in $R$ v. Secretary of State for the Home Department exparte Daly ${ }^{29}$ finds its origin in the judgment of the Privy Council in de Freitas v. Permanent Secretary of Ministry of Agriculture, Fisheries, Land and Housing ${ }^{30}$. In that case, Lord Clyde while deciding an appeal from Antigua and Barbuda, used South African and Canadian jurisprudence to formulate a three stage test for proportionality review.

A decision is proportionate if :

I. The legislative (or executive) objective is sufficiently important to justify limiting a fundamental right

II. The measures designed to meet the legislative (or executive) objective are rationally connected to it.

III. The means used to impair the right or freedoms are no more than necessary to accomplish the objective $^{31}$.

An analysis of the above three stage test would show that the main focus of the court would be to ensure that the decision making body takes the correct decision as regarding the least intrusive means. Hence in this model, proportionality is not about optimising costs and benefits, but about the pursuit of pre determined goals by the most efficient (or least intrusive) means. It does not raise question about the intensity of review, but only imposes a judicially generated criticism of the correctness in respect of necessity or efficiency. Thus this test treats necessity as the final stage of proportionality review and suppresses the balancing element ${ }^{32}$.

Such a conception of proportionality, called the state limiting conception of proportionality ${ }^{33}$, arises from the common law belief that courts exists to protect individuals and groups from other branches of the government namely legislature and executive. Courts therefore maintain a framework of legal rights which sets limits to the freedom of action of legislative and executive bodies. Within such a framework, only sufficiently important public objectives are permitted to limit the enjoyment of rights (i.e., first of the tests described above). This implies that there are legitimate public objectives that are not important enough to warrant limiting the enjoyment of rights. It is the responsibility of the court to act as a gate keeper here. However if a public objective is sufficiently important, any state action rationally connected to the objective and necessary to fulfill it is justified (i.e., second and third test described above). Thus carrying out important public objectives is the duty of the legislature and executive. All that the court does is to maintain an efficiency based oversight to ensure that there are no unnecessary costs to rights, that sledge hammers are not used to crack nuts or rather that sledge hammers are only used when nut crackers prove impotent ${ }^{34}$. Further at the necessary test stage the court will have to provide latitude to accommodate the margin of discretion of the decision maker. Thus judicial deference and judicial restraint are accommodated at the necessary stage.

\section{European Model}

The very concept of proportionality originated in nineteenth century Prussia ${ }^{35}$. This nineteenth century Prussian concept prescribed various tests. Those were accepted by the European Court of Justice in $R$ v. Minister of Agriculture, Fisheries and Food, ex parte Federation Europeenne de la Sante Animale (FEDESA $)^{36}$. Based on this case Julian Rivers outlines a four stage test as:

1. Legitimacy: Does the act (decision, rule policy etc) under review pursue a legitimate general aim in the context of the right in question?

2. Suitability: Is the act capable of achieving that aim?

3. Necessity: Is the act the least intrusive means of achieving the desired level of realisation of the aim?

4. Fair balance or proportionality in narrow sense: Does that act represent a net gain, when the reduction in enjoyment of rights is weighted against the level of realisation of the aim ${ }^{37}$

\footnotetext{
${ }^{27} I d$., p 176

${ }^{28}$ Ibid

${ }^{29}$ (2001) 3 All ER 433 (HL)

${ }^{30}$ (1999) 1 A.C. 69

${ }^{31}$ See Id., p 80

${ }^{32}$ See Supra n. 24 at p. 179

${ }^{33} I d$., p. 176

${ }^{34} I d$., p. 180

${ }^{35}$ See Supra n. 24 at p. 3696

${ }^{36}$ (1991) 1 C.M.L.R. 507

${ }^{37}$ Supra n. 24 at p.181
} 
From the analysis of the above formulation it is apparently clear that the said formulation is institutionally neutral. It is not defined to help courts determine its relationship with other organs of the government. It more importantly focuses on optimising or balancing the rights (which is seen as protected interest and which is being limited by the proposed action) with the public interest or aim (which the proposed measure seeks to achieve). Hence it is called as the optimisation conception of proportionality ${ }^{38}$.Even under this model the court has to allow latitude to accommodate the margin of discretion of the decision maker.

i) Judicial restraint: This latitude is taken into consideration only at the final stage of proportionality review namely the fair balance stage. This range of discretion is variable depending upon the subject matter and the nature of the affected rights. A large degree of restraint means that the court will be very unwilling to question the view of the decision maker that what is necessary to achieve a certain level of public interest is also balanced. A moderate degree of restraint means that the court will want to check that the costs and gains are indeed roughly commensurable. A small degree of restraint will reduce the set of necessary decisions to a minimum; the court will need to be convinced itself that the decision, rule or policy in question, even though necessary, really is the best way of optimising the relevant rights and interests ${ }^{39}$.

ii) Judicial deference: This aspect of the margin of discretion is much more complex because it is a question of relative institutional competence and the court's acceptance that its judgement is more likely to be correct if it relies on some other authority's assessment of some relevant matter. Hence this latitude can be accommodated at any or all of the stages of proportionality review depending upon the subject matter, nature of the affected right and the confidence that the court reprises on the competence of the decision making body involved. The court could simply accept the assertion of the public authority; or it could demand such assertions under oath or it could require the authority to reveal the factual basis for its judgments and so on. In short, the degree of deference means the extent to which the court will demand that the authority put procedural resources into answering the relevant questions reliably and expose that process to judicial scrutiny ${ }^{40}$.

Julian Rivers after carrying out an extensive analysis of the two models came to the conclusion that it is the European model that must be given preference over the British model due to fact that the European model has a higher degree of objectivity ${ }^{41}$.

\section{Indian Approach To The Doctrine Of Proportionality}

The Indian Supreme Court consciously considered the application of the concept of proportionality for the first time in the case of Union of India v. G. Ganayutham ${ }^{42}$. In that case the Supreme Court after extensively reviewing the law relating to wednesbury unreasonableness and proportionality prevailing in England held that the 'wednesbury' unreasonableness will be the guiding principle in India, so long as fundamental rights are not involved. However the court refrained from deciding whether the doctrine of proportionality is to be applied with respect to those cases involving infringement of fundamental rights ${ }^{43}$.

Subsequently came the historic decision of the Supreme Court in Omkumar v. Union of India ${ }^{44}$. It was in this case that the Supreme Court accepted the application of proportionality doctrine in India. However, strangely enough the Supreme Court in this case suddenly discovered that Indian courts had ever since 1950 regularly applied the doctrine of proportionality while dealing with the validity of legislative actions in relation to legislations infringing the fundamental freedom enumerated in Article 19 (1) of the Constitution of India. According to the Supreme Court the Indian courts had in the past in numerous occasions the opportunity to consider whether the restrictions were disproportionate to the situation and were not the least restrictive of the choices ${ }^{45}$. The same is the position with respect to legislations that impinge Article 14 (as discriminatory), and Article 21 of the Constitution of India ${ }^{46}$. With respect to the application of the doctrine of proportionality in administrative action in India, the Supreme Court after extensively reviewing the position in England came to a similar conclusion. The Supreme Court found that administrative action in India affecting fundamental freedoms (Article 19 and Article 21) have always been tested on the anvil of proportionality, even though it has not been expressly stated that the principle that is applied is the proportionality principle ${ }^{47}$. Thus the court categorically

\footnotetext{
${ }^{38} I d$., p. 174

${ }^{39} I d$., p. 203

${ }^{40}$ Ibid

${ }^{41}$ Supra n. 24

42 (1997) 7 SCC 463

${ }^{43}$ Id., p.479

${ }^{44}$ AIR 2000 SC 3689

${ }^{45}$ Id., p. 3697

${ }^{46} I d$., p.3698

${ }^{47}$ Id., p.3702
} 
held that the doctrine of proportionality is applicable to judicial review of administrative action that is violative of Article 19 and Article 21 of the Constitution of India. With respect to Article 14 of the Constitution of India, Supreme Court concluded that when an administrative action is challenged as discriminatory the courts would carry out a primary review using the doctrine of proportionality. However when an administrative action is questioned as arbitrary the principle of secondary review based on wednesbury principle applies ${ }^{48}$. The Supreme Court also held that punishment in service law is normally challenged as arbitrary under Article 14 of the Constitution, and hence only secondary review based on wednesbury principle would apply ${ }^{49}$. This according to the Supreme Court is because in such matters relating to punishments in service law, no issue of fundamental freedom or of discrimination under Article 14 applies ${ }^{50}$.

However even after a decade since the decision in Omkumar's case, no further progress has been made. The law regarding proportionality in India remains at what has been stated in Omkumar's case. The only advancement could be the vague observation in a few subsequent judgments that the doctrine of unreasonableness is giving way to the doctrine of proportionality ${ }^{51}$.

Thus, in India, under the current state of law, as declared by the Supreme Court, proportionality review with respect to administrative action has only limited scope. This is because, in India much of the administrative action is challenged before the courts primarily on the ground of arbitrariness and this can be challenged only on the ground of wednesbury unreasonableness. Thus in reality the decision in Omkumar's case has not significantly enhanced the scope of judicial review in India. No reason as such is given by the Supreme Court in Omkumar's case as to why doctrine of wednesbury unreasonableness alone should be applied to challenges under the head of arbitrariness. However there can be at least two reasons for this. First of all, the Supreme Court was simply accepting a similar classification in England by which proportionality review was applicable only when convention rights were involved and wednesbury principle alone was applicable when non convention rights were involved ${ }^{52}$. Secondly, just like Lord Lowry ${ }^{53}$ the Supreme Court may have feared a docket explosion when the threshold of review is lowered.

The latter of these two reasons cannot and should never be the reason for not allowing a better and more intensive standard of review. Initially there may be a increase in the number of cases, but when it becomes clear to the decision makers that the judiciary is adopting a much more intense standard of review, they would themselves reassess their decision making process and bring their decisions in tune with the new standard of review. As for the former reason, the distinction between convention and non convention rights as regards application of proportionality is fast disappearing ${ }^{54}$. Further more, the Supreme Court's distinction based on arbitrariness is not conceptually strong. First of all, the assumption behind this classification is that an administrative order which is arbitrary would seldom be violative of fundamental rights or is discriminatory. This is patently erroneous in most cases. For e.g., suppose a government employee is dismissed from service under the service law for attending a religious congregation, then the order is not only arbitrary but also violative of at least two of his fundamental rights namely his freedom of religion ${ }^{55}$ and his freedom to assemble ${ }^{56}$. Similarly an administrative act denying promotion for a sufficiently experienced government employee and at the same time promoting similarly placed persons will be per se not just arbitrary but also discriminatory. Secondly, when a petitioner having sufficient locus standi challenges an administrative act as arbitrary, he is doing so only because one or other of his rights - fundamental, statutory or common law - has been violated. If the classification made by the Supreme Court is adopted then the first task before the court is to determine which type of right has been affected. This is not an easy task for there can be no clear cut boundaries between fundamental rights and non fundamental rights particularly when the Supreme Court has itself given a very broad meaning to Article 21 of the Constitution of India. This task becomes even more difficult, when one considers the fact that usually an administrative act is violative of more than one right. Hence much of judicial time would be wasted in deciding the nature of the right. In the alternative, the judicial time could be effectively used in evaluating whether the decision maker has properly balanced the priorities while taking the decision. Obviously a variable intensity of proportionality review - based on the concept of judicial deference and judicial restraint - can be adopted depending upon the subject matter and the nature of the rights involved.

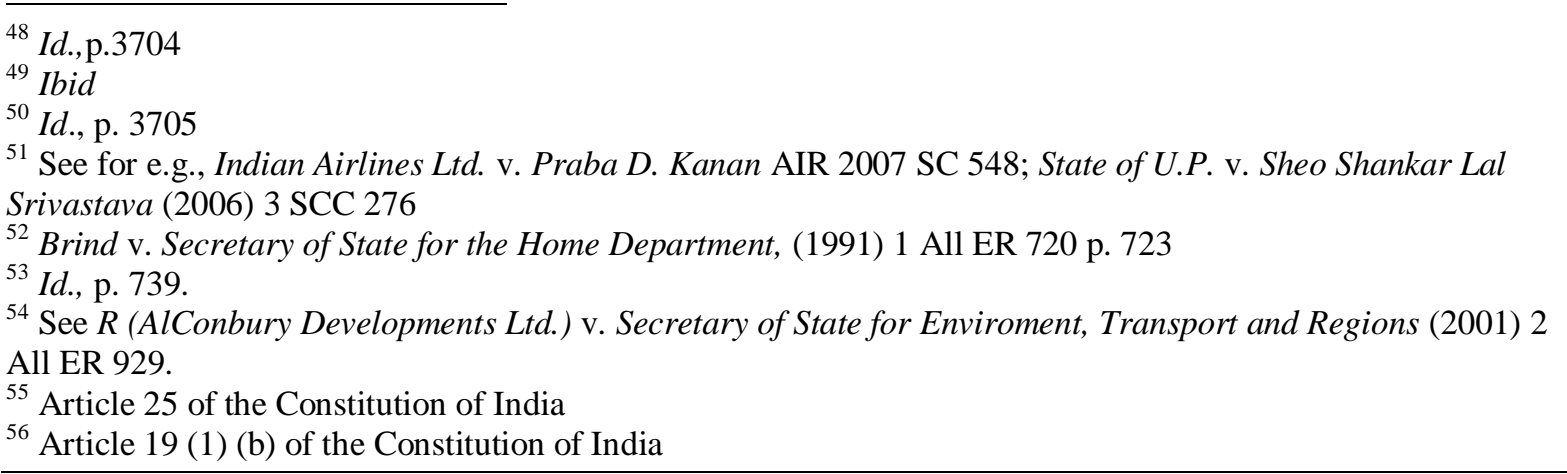


Equally important is the consideration whether the administrative action challenged as arbitrary should remain within the purview of wednesbury principle. For this, it is pertinent to look at the meaning of the word 'arbitrariness'. It is never an easy term to define with precision and hence the Supreme Court in the case of Shrillekha Vidyarthi v. State of U.P $P^{57}$ equated 'arbitrariness' with 'reasonableness ${ }^{58}$.

By equating arbitrariness with wednesbury unreasonableness, the decision maker escapes serious judicial review. But this is fast changing. Proportionality is fast replacing wednesbury reasonableness which the Supreme Court itself has observed in a large number of recent cases ${ }^{59}$. After all there is nothing wrong in a modern democratic society if the court examines whether the decision maker has fairly balanced the priorities while coming to a decision. At any rate, the intensity of proportionality review is variable depending upon the subject matter and the nature of rights involved.

The next question to be addressed is regarding which model - British or European - is to be adopted in the Indian context. A review of the various judgments of the Supreme Court would show that the Supreme Court has hardly given any consideration to this issue. This is primarily because the Supreme Court has never had a real opportunity to apply the doctrine of proportionality in judicial review of administrative action. Till now the Supreme Court has been merely stating the legal position of the doctrine of proportionality in the Indian legal system without actually applying the doctrine of proportionality in the sense it is today understood internationally.

After the conscious adoption of the doctrine of proportionality into Indian law in the Omkumar's case the only case where the Supreme Court has expressly adopted the doctrine of proportionality is the case of Sandeep Subhash Parate v. State of Maharastra ${ }^{60}$. In that case a student obtained admission to engineering course based on a caste certificate, which was subsequent to the admission, invalidated. However, he completed the course based on an interim order of the High Court. Yet the university refused to grand him the degree. This action of the university was held to be correct by the High Court. The Supreme Court in appeal directed the university to grand him degree subject to the appellant making a payment of Rupees one lakh, to re-compensate the state for the amount spend on imparting education to him as a reservation candidate. This, the Supreme Court claimed was done having regard to the doctrine of proportionality ${ }^{61}$. But the Supreme Court did not come to a finding that the university had failed to balance the various considerations before refusing to grant the appellant the degree. Also, the Supreme Court apart from mentioning the facts of the case failed to explain how it came to the conclusion regarding proportionality. At any rate the Supreme Court itself admitted that it was taking the decision under Article 142 of the constitution ${ }^{62}$.

Hence the choice between the European model and the British model in the Indian context will be a purely academic exercise. As suggested by Julian Rivers ${ }^{63}$ the choice would be in favour of the European model. Further such a selection gets some judicial backing from the decision of the Supreme Court in Omkumar's case wherein the Court while defining proportionality held that the legislative and administrative authority must be given a range of choice, but the courts can decide whether the choice infringes the rights excessively or not $^{64}$.This would indicate that the Supreme Court does intent that the fair balance stage (last stage) of the European model must be part of proportionality review. Hence the conclusive argument would be that the European conception of proportionality review should be the appropriate test that should be applied in the Indian context.

\section{Conclusion}

From the above analysis it is patently clear that at the international level wednesbury unreasonableness is on a terminal decline. It is fast being replaced by the doctrine of proportionality which is a much more intense form of review which seeks to see whether the decision maker has properly balanced the various factors that he has to take into consideration before rendering a decision. Further there are two competing models of proportionality, namely, European model and the British model. Of the two the European model is more efficient and objective.

In the Indian context it is amply clear that even though proportionality was made part of the Indian law as early as 2000, there is hardly any significant use of doctrine in India. Not only has the doctrine as adopted by the Supreme Court, limited application, but even within that applicable range, it has hardly been used.

\footnotetext{
${ }^{57}$ AIR 1991 SC 537

${ }^{58} I d$., p. 554

${ }^{59}$ See Supra n. 51

${ }^{60}$ (2006) 1 SCC 501

${ }^{61} I d .$, p. 508

${ }^{62}$ Id., p.507

${ }^{63}$ Supra n. 24

${ }^{64}$ Supra n. 22 at p. 3697
} 
However sooner or later courts in India will have to actively consider implementing the doctrine of proportionality in all cases coming before it irrespective of whether fundamental or ordinary rights of citizens / persons are involved. This is because of the fact that human rights jurisprudence that has come to dominate the legal system includes not just fundamental rights but other rights also. Hence the urgency of adopting the doctrine of proportionality cannot be overlooked for otherwise steam hammers would increasingly be used to crack nuts even if nut crackers are sufficient.

\section{Reference}

[1] Craig, P.P., Administrative Law (London: Sweet \& Maxwell, 1994).

[2] HWR Wade and CF Forsyth, Administrative Law (Oxford: Oxford University Press, 2004).

[3] John Alder, General principles of Constitutional Law and Administrative Law, (Hampshire: Palgrave Macmillan, 2002).

[4] Justice C.K. Thakkar, Lectures on Administrative Law, (Lucknow: Eastern Book Company, 2003).

[5] Allan T.R.S., Human Rights and Judicial Review: A Critique of “Due Deference”, (2006) 65 (3) C.L.J 671.

[6] Julian Rivers, Proportionality and Variable Intensity of Review, (2006) 65 (1) C.L.J.174.

[7] Justice Anand Byrareddy, Proportionality vis-à-vis irrationality in administrative law, (2008) 7 SCC J-29.

[8] Mark Elliott, The Human Rights Act, 1998 and the Standard of Substantive Review, (2001) 60 (2) C.L.J. 301

[9] Paul Craig, The Courts, The Human Rights Act and Judicial Review, (2001) 117 L.Q.R. 589. 